\title{
DIFFERENCE IN ACCEPTABILITY AND LEVEL OF PREFERENCE BETWEEN MODIFIED AND STANDARD SUPPLEMENTARY FEEDING IN UNDERNOURISHED TODDLERS AT JANTI COMMUNITY HEALTH CENTER, MALANG
}

\author{
Sugeng Iwan Setyobudi, I Nengah Tanu Komalyna, Nurulloh
}

Nutrition Department Malang State Health Polytechnic

\begin{abstract}
Background: In East Java, the prevalence of $36 \%$ of toddlers did not finish standard supplementary feeding biscuits. Some contributed factors were disfavor of children (66.6\%), forgotten to feed (3.9\%), incompatible (0.5\%), eaten by another family member (23.4\%), and others (5.6\%). This study aimed to determine the difference in acceptability and level of preference between modified and standard supplementary feeding in undernourished toddlers at Janti Community Health Center, Malang, East Java.

Subjects and Method: A quasi-experimental study with one group pretest-posttest design was conducted at Janti Community Health Center, Malang, East Java, in July 2019. A sample of 16 under-five malnourished children aged 12-59 months was selected by purposive sampling. The dependent variables were acceptability and the level of preference of under-five malnourished children. The level of preference was categorized into taste, texture, color, and aroma. The independent variables were standard (biscuit) and modified (chocolate ball and chocolate pudding) supplementary feedings. The data were collected by questionnaires. The data were analyzed by Kruskal Wallis.

Results: The highest level of acceptance obtained in chocolate ball, followed by chocolate pudding and standard biscuit, and it was not statistically significant $(\mathrm{p}=0.112)$. The highest preference for taste was chocolate ball, followed by standard biscuit and chocolate pudding, and it was statistically significant $(p=0.022)$. The highest preference for texture was chocolate ball, followed by chocolate pudding and standard biscuit, and it was statistically significant $(\mathrm{p}=$ 0.025). The highest preference for color was chocolate ball, followed by chocolate pudding and standard biscuit, and it was statistically significant $(\mathrm{p}=0.022)$. The highest preference for aroma was standard biscuit, followed by chocolate pudding and chocolate ball, and it was not statistically significant $(\mathrm{p}=0.190)$.

Conclusion: There are no significant differences in the level of acceptance between standard (biscuits) and modified (chocolate ball and pudding) supplementary feedings among undernourished toddlers. The highest preference for taste and texture is in chocolate ball feeding. The highest preference for color is in standard biscuit feeding.
\end{abstract}

Keywords: standard, modified, supplementary feeding, acceptance, preference level

\section{Correspondence:}

Sugeng Iwan S. Nutritional Study Program, School of Health and Sciences, Malang. Jl. Besar Ijen No.77C, Oro-oro Dowo, Klojen, Malang, East Java, 65119. Email: sugengiwan66@gmail.com. Mobile: +6281330200826 . 